\title{
Straddling the Wall: Comparative Framing of Trump's Border Wall in U.S. \& Mexican Newspapers
}

\author{
Nathian Shae Rodriguez \\ San Diego State University, USA \\ Mariana De Maio \\ Lehigh University, Pennsylvania, USA
}

\begin{abstract}
Donald Trump's most notorious promise before and during his presidency was the construction of a border wall. The issues surrounding new construction of Donald Trump's border wall (both physically and rhetorically) are complex and the outcomes are difficult to predict. The study examines how Trump's border wall was framed in online newspaper publications of the international border cities of San Diego, California and Tijuana, Mexico, and in El Paso, Texas, and Ciudad Juarez, Mexico. Specifically, the study employs a comparative framing analysis using the John Agnew's (2008) theoretical lens of borders as equivocal spaces of dwelling that bring about both benefit and harm - the standard of a decent life. The analysis revealed the frames of: Mexico will pay for the wall; DACA as leverage; political contention; protest and dissention; environmental impact; immigration package; separation and divisiveness; safety and security; and economic consequences. A majority of the content published in the U.S. was produced locally, however, most of the content published in Mexico was from news agencies, except for the opinion pieces that were locally produced for outlets on both side of the border.
\end{abstract}

Keywords: border, border wall, framing, global journalism, Mexico, Trump.

Donald Trump's major campaign platform for winning the 2016 U.S. Presidential Election was to build a wall on the U.S.-Mexican border, funded by Mexico. After winning the presidency, Trump made the wall a priority, employing rhetoric of danger and threat from migrant refugees and Mexican immigrants. His administration began accepting prototype designs from contractors in the summer of 2017 and construction of the prototypes began in August 2017. It is important to note that border fencing has existed along the U.S. southern border since the mid-1990s. The Illegal Immigration Reform and Immigrant Responsibility Act of 1996 increased the number of Border Patrol agents, fence structure, and other surveillance technologies at the border, as well as added criminal penalties for undocumented immigrants who stayed in the U.S. beyond statutorily-defined time periods or committed crimes. The U.S. border wall has been, and continues to be, a contentious issue in both major U.S. political parties. Conservatives questioned how the wall would be funded, while liberals highlighted the many ethical, environmental, and economical ramifications. As of January 5, 2021, the U.S. had replaced or built new wall along 452 miles of the border. Although all construction was halted by President Biden on January 31, 2021, the local impact of the wall in the border cities it traverses is still being assessed. 
The issue of a border wall is politically understood through a broader framework of national borders, lines on a ground that are classified based on the purpose in which they serve-political, social, or economic. Borders, when conceptualized as mere divisive boundaries, are arguably normative, fixed, and reductive. Thus, many academics go beyond a line-in-the-sand approach and theorize borders as dominant discursive processes that apportion physical territory, separating people from one another, and emphasize lived experiences that examine borders through lenses of (im)mobility which connect populations and communities in border areas (Agnew, 2008; Anzaldúa, 2012; Brown, 2010; Coronado \& Mumme, 2020; Keck \& Clua-Losada, 2021; Sarabia, 2020). The goal of the current study is to build on theorizations of borders as dominant discourses and address borders as equivocally complex, while at the same time acknowledging physical borders as spaces of dwelling and experiential impact, rather than national zones (Agnew, 2008). This acknowledgment, termed standard of a decent life, can aid in highlighting both the negative and positive effects of borders.

The current study focuses on transnational journalistic accounts of the border wall to better understand dominant discourse in media that may influence how textures of a new border wall are framed in a transnational media landscape. From a journalistic perspective, most significant news sources are still aggregated by national media (Curran et al., 2017; Mogos et al., 2021) and devote less than a quarter of their time to foreign news (Aalberg et al., 2013). Although the ubiquity of the Internet has increased the global reach of news sources, websites in most countries continue to be nationally-focused (Curran et al., 2017). Those international news stories that do capture and sustain media attention tend to focus on issues that affect two or more countries of the world at large, including the respective country of the media source (Duan \& Takahashi, 2017; Jang, 2013; Konieczna et al., 2014; Mogos et al., 2021; Rosas-Moreno \& Bachmann, 2012; Shehata \& Hopmann, 2012).

We argue that individuals come to understand issues surrounding the U.S.-Mexican border and the construction of Trump's border wall through the ways in which media define and construct political issues or public controversies, a process known as framing (Entman, 1993, 2004; Goffman, 1974; T. Nelson et al., 1997b). Specifically, the study examines how Trump's border wall (physically and rhetorically) has been framed, in both benefits and harms, in news publications based in the international border cities of San Diego, California and Tijuana, Mexico; and in El Paso, Texas, and Ciudad Juarez, Mexico. We highlight nine frames of: Mexico will pay for the wall; DACA as leverage; political contention; protest and dissention; environmental impact; immigration package; separation and divisiveness; safety and security; and economic consequences and link them to considerations about a 'standard of a decent life' developed by Agnew (2008).

\section{Literature Review}

\section{The Border}

Borders serve as lines of division on the ground, however they are symbolic in nature, specifically in the purposes they serve and the ways in which they serve them - for example as devices for political, social, economic, and environmental issues (Agnew, 2008). Specific to Trump's border wall, there has already been research to support its symbolism and influence over foreign policy, immigration law, human rights, activism, border security, and linguistic content (Febriyanti, 2017; Gravelle, 2018; Hinton, 2017; Keck \& Clua-Losada, 2021; Rivers \& Ross, 2020). The interest in adding a larger, impenetrable physical barrier on the southern U.S. border, 
to either separate or protect as Trump's regime has expressed, is a paradox of sorts according to Brown (2010). She argues such old-fashioned, rugged barriers are out of sync with the modern and confident positions of the very nations building those barriers, as well as the forces of immigration and terrorism that they claim to guard against.

A border wall has existed for decades and Trump's reiteration of border wall discourse for political mobilization is nothing new, borders have often been used as a rhetorical device to convey divisions, not just movement (Agnew, 2008). Borders serve as liminal physical markers to divide space and people (McGahern, 2017), and that is exactly what Trump's border wall has done. Dichotomies tend to form around border issues and position people as either for or against an issue. For example, in Arizona, pro-immigration activists were positioned against another group in favor of immigration restrictions, however both groups saw the state as the cause of the problems (Elcioglu, 2017). In regards to movement, borders become the liminal space where state sovereignty is policed and challenged through processes of identification, classification, and migration (Andreas, 2009; Keck \& Clua-Losada, 2021; Vaughan-Williams, 2009). The state not only controls the movement of people, but also the movement of goods (Heyman \& Ackleson, 2010). Borders become a space of 'unrelieved domination of capital and God-sanctioned political violence' (Brown 2010, p. 23). A total of 130 individuals have died as a result of an encounter with U.S. border agents between January of 2010 and July of 2021 (SBCC, 2021).

Borders are also a place of culture, lived experiences, and identity - each not mutually exclusive, but rather constitutive of one another. Anzaldúa (2012) theorizes the U.S. southern border with Mexico as a postcolonial condition for its inhabitants, specifically Chicanos, created by an interwoven complexity of culture, mythology, religion, and language - a mestiza consciousness. The border is an unpredictable, undetermined territorial space between two worlds in which a mestiza identity is embedded, making the lived experiences of those who reside in the borderlands qualitatively distinctive - an experience neither Mexican or American, informed by indigenous Mexican people and Angelo subjectivities, and possessing possibilities for new forms of knowledge, politics, and epistemologies. The lived experiences of, as well as the uncertain possibilities in, the borderlands are unstable, precarious, and intrinsically bounded to transition and transformation. Anzaldúa (2012) also recognizes that the border as a space is socially and ideologically fashioned. She argues we must theorize borders not only as geographic space and lived experiences, but also in terms of the social hierarchies, power dynamics, and structural injustices that are constructed and maintained by borders.

\section{The Standard of a Decent Life}

Drawing upon Anzaldúa's argument for a multi-level approach, the current study turns to John Agnew's (2008) theorization of borders as a standard of a decent life. Agnew openly acknowledges the ambivalent nature of borders and maintains, 'We need to see a border not as that which is either fixed or that as such must be overcome, but as an evolving construction that has both practical merits and demerits that must be constantly reweighted' (p. 175). His theorization is organized into four points. First, the categorizations of identities established by 'state-based inclusionary and exclusionary practices that are more and less discriminatory and effective in given areas' (p. 184). The border serves as a space to sort which bodies are worthy of crossing over based on privilege and identity politics. This categorization process, coupled with the enforcement of identity checks, may lead to the potential criminalization of an entire population, which has been evident in Trump's disparaging rhetoric about Mexicans (Rivers \& Ross, 2020; Romero \& Zarrugh, 2017). 
Second, the symbolism of the border as a physical, tangible line on a map that 'influences territorial imagination of whose security is at stake and who most threatens it' (Agnew, 2008, p. 185). The border is thought of as a physical barrier of personal, as well as national security. Third, the selection and separation of goods and people to 'enhance or maintain unequal cross-border exchanges' (Agnew, 2008, p. 185). In the context of the U.S.-Mexican border, the border separates the gratifications of the wealthy from the aspirations of the poor, thus inviting cross-over (Nelson, 2011). Finally, the policing of borders to defend the 'territorial sovereignty which serves to underpin both liberal and democratic claims' (Agnew, 2008, p. 186). The border serves as both a physical and symbolic marker of national political order - the nation-state.

Agnew's theorization considers borders physical territorial spaces in the borderlands as spaces of dwelling and habitat, rather than of national occupancy. Agnew (2008) positions this approach as one that considers negative and positive impacts of borders - both practically and ethically. Thus, the standard of a decent life, in conjunction with framing theory, is well-suited as a lens to theorize borders as geographic space, lived experiences, social hierarchies, power dynamics, and structural injustices in news frames. The current study seeks to explore the ways in which newspapers located on the physical territorial spaces of the U.S.-Mexican border frame the idea of Trump's border wall in regards to benefits and harms for a decent standard of life.

\section{Framing}

The way people think about controversial political issues, such as building a wall in the U.S.-Mexican border, may be shaped by the way media cover such topics. Framing is the process used by media to define and construct 'a political issue or public controversy' (T. Nelson et al., 1997a, p. 221). In his seminal work, Goffman (1974) explains frames are influenced by our cultural heritage. To illustrate the concept, Goffman gives the example of a picture frame where the frame represents the structure and the picture represents the content. Framing plays a central role in the process of defining social problems, raising public awareness and establishing specific ways of interpreting them (Entman et al., 2009; Hove et al., 2013). When news organizations frame political and social issues in certain ways, they are showing plausible causes and consequences and presenting ways of how to solve the problem (Entman, 1993, 2004).

Framing theory assumes an issue can be interpreted in many ways and from various points of view. Framing is a social construction of a social phenomenon (Chong \& Druckman, 2007) and helps explain how an issue is presented to the public (Entman, 2007; Fryberg et al., 2012; Gross \& D'Ambrosio, 2004). The way the public understands and interprets the construction of a new section of wall along the 2,000-mile U.S.-Mexico border is influenced by media framing. Framing can significantly shape public opinion (Iyengar, 1991; Nelson \& Kinder, 1996). Frames lead an individual to pay attention to specific characteristics and patterns of an issue, reducing the complexity of it to, seemingly, core elements (T. Nelson et al., 1997a). How people on both sides of the border look at the controversy of not only the border wall, but also Trump's campaign promise to build the wall, is heavily influenced by the way media frames the phenomenon. The study will compare and contrast the coverage in four online publications based in the bordering cities of San Diego and Tijuana, as well as in El Paso and Ciudad Juarez. 


\section{International Framing/Comparative Studies}

Although globalization has brought about an increase in international news, international media is still segmented by country, with foreign news accounting for less than a quarter of content (Aalberg et al., 2013; Curran et al., 2017). International news stories that highlight global or transnational issues tend to capture the interest of news sources (Cooper et al., 2021; Löffelholz \& Weaver, 2008). Previous research has investigated these transnational issues by comparing the news content from two or more countries. Issues such as environmental concerns (Duan \& Takahashi, 2017; Liobikienė et al., 2017; Olive \& Delshad, 2017), nuclear weapons (Jang, 2013), climate change (Konieczna et al., 2014; Lück et al., 2018; Shehata \& Hopmann, 2012), migration/immigration (Cooper et al., 2021; Di Renzo, 2017; Lawlor, 2015), war and conflict (Camaj, 2010; Pantti, 2013; Zhang \& Hellmueller, 2017), social justice (Akhavan-Majid \& Ramaprasad, 1998; Elena, 2016; Harlow \& Johnson, 2011), and the economy (Kaiser \& Kleinenvon Königslöw, 2017) have been studied.

Specific to borders, much of the framing literature has found borders to be framed in much broader issues such as migration (Di Renzo, 2017; Varjú \& Plaut, 2017), immigration (Cheng et al., 2010; Lawlor, 2015; Muñiz, 2011), youth migrants (Antony \& Thomas, 2017), human trafficking (Marchionni, 2012) security (Frederking, 2012; Vultee, 2010), and voting practices (Fernandes \& Shumow, 2016). Important to note is that a disproportionate amount of border studies focus primarily on countries that receive immigrants and tend to overlook countries of origin. One of the few studies that counters this academic hegemony investigated how immigration was framed in digital Mexican newspapers. Researchers found there was still a prevalence of news imported from the U.S. with little attention given to issues south of the U.S.- Mexican border (Muñiz, 2011).

The current study looks at framing from a transnational perspective. Previous research has demonstrated complex and changing political cultures in regards to migration and movement. Findings indicate media framing, as well as counter-framing, of immigration politics of the host country are contextual and do not often easily transfer between host countries, particularly in regards to right- and left-wing media (Varjú \& Plaut, 2017). Transnational framing studies focused on the mobility across borders have also found little variance between local and national media frames, concluding that both types of media emphasize both local and national consequences (Cooper et al., 2021; Lawlor, 2015). There is also evidence to suggest that Western media frames are influenced by national governments, as demonstrated in England and the U.S. (Marchionni, 2012).

Studying journalism from a global perspective introduces multiple and more diverse perspectives from global players and creates an awareness of interconnected global audiences (Reese, 2008). Although global journalism can move research beyond national frames of reference and expose the similarities and linkages across work cultures (Cottle, 2009), it is important not to rule out national and cultural differences that may exist in news creation and interpretation. There is much value in comparing both similarities and differences, rather than just one over the other (Jenkins, 2014). Employing global journalism to examine power, space, and identity can provide a better understanding of the lived experiences of individuals in relation to both their local culture and a global culture at large ( Berglez, 2008; Cooper et al., 2021).

Global journalism is a well-suited compliment to Agnew (2008) contention of viewing physical territorial spaces in the borderlands as spaces of dwelling and habitat, rather than of national occupancy. Considering framing theory through a global journalistic approach and Agnew's (2008) practical and ethical position of negative and positive impacts of borders, we pose the following research questions to guide our study: 
RQ1: How do newspapers in the United States frame Trump's border wall in comparison to newspapers in Mexico?

RQ2: How do frames used by the United States and Mexico operationalize Agnew's standard of a decent life?

\section{Positionality}

The authors' decision to center the border wall and the discourse around it was based on both subjective positionalities and geographic location. The first author identifies as a cisgender queer male with Mexican American roots who grew up in the borderlands of Texas. The second author identifies as a straight cisgender woman who migrated from Argentina to the United States. At the time of writing, both authors lived and worked in the borderlands of Southern California. The authors are media and journalism scholars who are academically and pragmatically committed to researching the lived experiences of traditionally marginalized populations and their relationship with media. These identities and lived experiences, in conjunction with our political orientation, may have shaped data collection, analysis, and interpretation. Throughout the research process the authors remained self-reflective and conscious about the ways their positionalities, phenomenology, and affiliations influenced the progression and development of this study. The intention of this study is to compare and contrast international journalistic perspectives on Trump's border wall and its implications on the lived experiences of those residing in the borderlands.

\section{Method}

To explore how newspapers in the United States frame Trump's proposal to build a border wall in comparison to newspapers in Mexico, four newspapers from major urban cities on the southern U.S. border were analyzed. The newspapers were selected because of their proximity to the border, their significant impact on border discourse, and their past involvement in national border policies. A textual analysis was employed to uncover news frames, analyze meaning, and correlate theory (Lindlof \& Taylor, 2002; Zaharopoulos, 2007).

\section{Newspaper Selection}

The Trump administration announced on August 31, 2017, that it chose four companies to build concrete prototypes of the president's much-touted border wall. Construction of the prototypes, that took place in San Diego, was the first step in fulfilling Trump's campaign promise of building a 'big, fat, beautiful wall' stretching along the 2,000-mile U.S.-Mexico border (Finnegan, 2016, p. 6). The major urban cities of San Diego, El Paso, Tijuana, and Ciudad Juarez were selected due to their proximity to the border, they encompass physical territorial spaces of dwelling that would be most directly affected by Trump's wall. Additionally, both U.S. cities have historically had anti-immigration legislation enacted in their respective cities. In 1993, El Paso's Operation Blockade/Hold-the-Line outlined territorial denial, a 'prevention through deterrence' strategy' that impeded migrants from entering the U.S. 'through the forward deployment of Border Patrol agents and increased use of surveillance technologies and support infrastructure' (Nevins, 2001 , p. 2). This was counter to the previous strategy of apprehending migrants after they crossed the border. The strategy was later used as a model to implement Operation Gatekeeper in San Diego in 1994. The cities also had major newspapers with an online presence, providing enough sample 
content. The newspapers selected were The San Diego Union Tribune and El Paso Times in the U.S. and El Sol de Tijuana and El Diario de Juárez in Mexico.

The San Diego Union Tribune was owned by the Tribune Company during the period of analysis, however, as of June 18, 2018, the paper was owned by Patrick Soon-Shiong (Stone, 2020). The newspaper's average daily paid circulation averages around 121,321 (Bauder, 2017). El Paso Times is the only English-language daily in El Paso, Texas and is owned by Gannett; it has an average daily paid circulation of 35,023 (About Us, n.d.). El Sol de Tijuana has a daily circulation of 5,682, which includes almost 200 distributed in the United States; El Diario de Juárez has an average circulation of 55,377, which includes more than 14 thousand distributed in the United States (Gobierno de México, 2021). The San Diego Union Tribune leans more liberal and the El Paso Times is more moderate liberal (Media Bias/Fact Check, 2020a, 2020b). At the time of writing, there was not academic nor professional research on the political leanings of the two Mexican newspapers.

\section{Data Collection and Analysis}

Stories were collected from the newspaper's online sites utilizing each newspaper's search engine. The keywords 'Trump and wall' and 'Trump and muro [wall]' were used to collect stories from August 31, 2017, (the day the prototypes began construction) until October 26, 2017 (the day completion of prototypes was announced), providing a six-week sample frame. Although all stories were accessed online, each story also ran in a respective physical printed hard-copy. A total of 241 stories were qualitatively analyzed in English and Spanish. Axial coding was utilized to identify and group organic themes that emerged from the data, refining preliminary categories in each iteration of coding until themes could not be reduced any longer (Lindlof \& Taylor, 2002).

\section{Findings}

Newspapers in the U.S. and Mexico used the following themes to frame the discussion around building the wall along the border: (1) Mexico will pay for the wall, (2) DACA as leverage, (3) political contention, (4) protest and dissention, (5) environmental impact, (6) immigration package, (7) separation and divisiveness, (8) safety and security, and (9) economic consequences.

Most of the content published in The San Diego Union Tribune and El Paso Times was produced locally, however, most of the content published in the Mexican outlets was from news agencies, except for the opinion pieces that were locally produced for all four papers. What follows is a summary of the themes found in the coverage.

\section{Mexico Will Pay for the Wall... Eventually}

One of the more controversial promises made by Trump to his supporters during the campaign was that the Mexican government would pay for the construction of the border wall (Finnegan, 2016). The U.S. media coverage analyzed from San Diego and El Paso employed the word 'controversy' when referring to this issue. There was a veiled narrative surrounding whether or new portions of the wall would be built, and if so, who would pay for it. Phrases like 'adding to an atmosphere of distrust is another controversy: Trump's continued insistence that Mexico will pay for his planned wall' (Showley, 2017) and 'the Mexican president has vehemently refused to pay for the wall' (McDonnell, 2017b) illustrate the dispute and eventuality of the divisive structure. 
The cost of building the wall and its political implications were scrutinized by the U.S. media in their opinion pages as evidenced by, 'it is absurd to hold the entire economy of the United States hostage for the president to pay off on one of his campaign promises' (Showley, 2017). Many articles provided 'better ways to spend money than a border wall' (Flores, 2017) and suggested using money for bridges, medical aid, and education. Phrases such as 'helping Mexico be a better place to live and work is the only way to stop illegal immigration' (Vines, 2017) also pointed to the wall as a band aid and not a viable solution.

On the other side of the border, publications in Tijuana and Ciudad Juarez were more explicit about Trump's difficulties to find funding for his desired wall: 'Trump threatened Congress to shut down the government if he didn't get funding for the wall' (“Trump Da March", 2017) and 'So far, the Capitol has pending bill of $\$ 1.5$ billion to start construction of a portion of the border wall in 2018; with opposition from the Democratic minority, Republicans hope to approve the initiative in December 2017' (Associated Press, 2017a). Mexican newspapers sampled in the timeframe did not reference Mexico's opposition to pay, nor did they highlight key Mexican figures like Vicente Fox who publicly condemned payment for the wall.

\section{An Immigration Package}

Media on both sides of the border revealed the border wall as part of an immigration package that is central to Trump's agenda. The wall is part of a larger package that includes immigration reform, childhood arrivals, and revoking federal funding to sanctuary cities. Newspapers highlighted that one of the main goals of these policies is to deport people who are presumably taking jobs away from the domestic labor force (Demirjian, 2017). It was also stressed that Congressional Democrats and immigrant rights groups criticized the list of border security priorities from the Trump administration as inhumane because it holds DACA ${ }^{1}$ hostage in a budget negotiation to fund the wall and a political battle to reduce funding and sanction sanctuary cities (Mekelburg, 2017b). Under the immigration reform umbrella, students benefiting from DACA were being used as leverage to force Congress to approve funding for the wall: 'Now, some top Republicans see an opening to extract Trump's other immigration priorities for building a wall along the border with Mexico or limiting legal arrivals, positioning the young Dreamers as bargaining chips in a broader compromise' (Mascaro, 2017).

Newspapers in Mexico focused more on DACA than other parts of Trump's immigration package. Both newspapers clearly stated that Trump demanded funding to build the border wall in exchange for finding a solution for the 'dreamers' (Associated Press, 2017c; "Mientras Pence elogia", 2017). Mientras Pence elogia Mexican newspapers were particularly interested in pointing out that the White House will not concede on DACA without getting something in return ("Mientras Pence elogia", 2017). The Mexican newspapers used Democrats as a way to frame opposition to DACA negotiations. They stated Trump's demands are not satisfactory to the Democrats (Reuters, 2017) and that Democrats considered Trump's demands to be cruel (Hastings, 2017).

\footnotetext{
1 Deferred Action for Childhood Arrivals (an administrative procedure protecting undocumented minors from deportation who came to the United States before June 15, 2012).
} 


\section{Political Contention}

The political economy of legislative negotiating strategies in issues such as immigration were also used to frame the border wall. The border wall, among other parts of Trump's agenda, created a battle ground in Washington D.C. and pitted parties against one another. Quotes like, 'Democrats could block the spending bill in the Senate, where it requires a 60-vote majority and Republicans control 52 seats' appeared often and used as political scorecards (Paletta et al., 2017). There was not much difference between the four papers and all framed the political contention primarily on Trump's 'incompetence' and 'inexperience' (Ulloa, 2017).

The U.S. and Mexican articles suggested that Democrats do not support funding the wall, the revocation of DACA, the immigration reform, nor a reform of NAFTA. Conversely, Republicans often cited safety concerns, economic strain, and drug trafficking as legitimate reasons to fund the wall. Within-party complexities were also evident as in 'Nevada Rep. Mark Amodei tries to be a 'pro-immigration Republican' in the era of Trump' (Collins, 2017) and other stories that highlighted the tension Trump's antics have caused among Republicans. Notably, more Republicans were cited than Democrats in U.S. stories. In sum, the political debate is impregnated with predictable ideological stands.

\section{Protests and Dissention}

Restricting immigration and threatening deportation generated a natural reaction for those directly affected, as well as their advocates. Many of the articles published on both sides of the border highlighted public demonstrations, both physical and online, surrounding the building of the wall. The newspapers included some of the chants and slogans used by protestors to demonstrate the intensity of the opposition, 'about two dozen anti-Cruz protesters were shouting, 'Loser Ted,' while a slightly smaller group of supporters shouted back, 'Get an education!' (Borunda, 2017b). In some instances, articles highlighted protests that surrounded the many complex issues of Trump's immigration agenda, 'activists pray for the continuation of DACA during a protest at the border wall in Tijuana on Monday’ (McDonnell, 2017d).

The San Diego Union Tribune, specifically, covered the notable absence of protestors at the construction site of the prototypes: 'Hiram Soto said his organization and others were not mounting a protest because that wall was "political theater" that had no chance of ever being fully built out, as Trump has promised, because of Congressional opposition and no funding' (Moran \& Davis, 2017). The paper showcased strategies of protesters and had the most activist sources amongst all the papers. Mexican newspapers focused more on the precautions taken for protestors and highlighted aggressive language. El Sol de Tijuana published 'Mexican and US authorities have "armored" the areas surrounding the construction of prototypes of the Trump Wall, to avoid social protests by nonconformists' (Hernández, 2017).

\section{Safety and Security}

Increased safety for U.S. citizens is cited in the U.S. articles as an important concern to lawmakers and citizens in relation to the border. 'We must have physical barriers-including a wall where necessary and fencing when appropriate, the right technology, and more personnel in place to enforce our laws and detain those attempting to enter illegally' (Mekelburg, 2017a). Some articles cited arguments that the country is not secure (Winkley \& Repard, 2017), whereas others showcased data that suggest the border patrol has become more effective over the years and border 
is not as easy to cross as most people think (Moran, 2017). Additionally, there was skepticism about the wall's effectiveness: 'it would not improve safety or deter people looking to enter the country' (Brito, 2017).

Both U.S. papers interviewed local law enforcement and high government officials when they visited their respective cities. For example, The El Paso Times interviewed Senator Ted Cruz and highlighted his localize efforts: 'One of the things I have urged the President, I've urged the Department of Homeland Security to make these resource allocation decisions in close consultation with local authorities, with local officials, local law enforcement with the men and women of the community' (Borunda, 2017b). The San Diego Tribune showcased Jeff Sessions visit to the city and his assessment of security.

The Mexican media took a different approach to security and did not mention any visits to the border by U.S. officials. Rather, the papers framed the issue of security by highlighting possible increases in human trafficking. They argued a new border wall would not stop migrants from crossing the borders but increase other means of crossover. For example, the border wall may benefit coyotes and human smuggling (Caballero, 2017). The papers accompanied this with comments from U.S. border patrol representatives such as 'we are committed to protect the border and this includes building walls' (Reforma, 2017b).

\section{Environmental Impact}

The U.S. and Mexican newspapers drew attention to the environmental impact of building a wall along the border: 'The wall is a textbook example of habitat fragmentation, a primary driver of extinctions worldwide. Jaguars, Mexican wolves, and ocelots are just a few of the many species that will be harmed' (Bixby, 2017). Coverage in Mexico also included the opinion of experts from that country about the negative environmental impact of building the wall (López, 2017). Both newspapers highlighted the species that were indigenous to the area and the fact that a wall built directly on the border would threaten extinction.

The papers also included mentions of lawsuits filed by advocacy groups and the State of California, most emphasizing the impropriety of Trump's disregard of federal laws protecting wildlife and the environment (AFP, 2017; Associated Press, 2017b; Morrissey, 2017; Reforma, 2017a). Framing the border in terms of legality not only provided a potential solution for stopping the building of the wall, but also directly criticized the ethics of Trump and his administration. Environmental protection on the border requires binational cooperation that has fallen short of a "highly integrated and strategic commitment to the sustainable management of the border environment" (Coronado \& Mumme, 2020, p. 160).

\section{Economic Consequences}

The most localized framing theme was that of direct economic consequences to the border cities in regard to a new border wall. Only the U.S. papers mentioned the impact a new wall would have on trade, tourism, and jobs. Statements such as 'San Diego benefits economically from the binational bond we have with Mexico' (Gómez, 2017) were accompanied with statistics on how much money is put into the economy by immigrants and how much money is exchanged in the border regions compared to other parts of the country. The papers highlighted the vast amount of jobs that are filled by Mexicans crossing the border daily.

There were also direct mentions of the strong political position of the Mexican government supporting the trade agreement that Trump pointed as one of the main culprits for the erosion of 
manufacturing jobs in the United States (McDonnell, 2017a). Allegedly, a revocation of NAFTA would negatively impact the Mexican economy as it would no longer be able to export its manufactured goods from the maquiladora complex to the United States. Issues such as NAFTA and jobs held by Mexicans with work VISAS were framed as being directly affected by the ideology of a border wall.

\section{Separation and Divisiveness}

An emotionally charged issue embedded in the larger discussion of human rights is found in the sampled U.S. media, where tales of families ripped apart by immigration policies illustrate the gravest impacts on people and advocates argue that the battle to protect immigrants has only just begun (Borunda, 2017a; McDonnell, 2017c). There were stories of families who have been living in the border cities for generations and whose family members crossed over in search of a better life. U.S. papers focused on local events in El Paso and San Diego where families would reunite with their loved ones through existing border fencing, briefly touching each other others hands.

This same use of affect and personal narratives was found in the Mexican newspapers. Tales of heartbreaking border encounters among family members living on both sides were also used to illustrate the human toll left behind by these policies (Notimex, 2017). Framing the border in terms of emotion and loss is a powerful tool to convey the direct and localized impact of a border wall. Within this frame, the border was framed as both a tangible, physical barrier and an ideological division.

\section{Standard of A Decent Life}

The second research question asked how frames used by the U.S. and Mexico operationalize the standard of a decent life? Based on the thematic frames discussed above, both U.S. and Mexican newspapers used a mix of two broad categories of framing. The frames that most embody a 'national zone' type of approach were those of political contention and immigration package. Articles using a national zone frame tended to include national sources, such as highprofile members of Congress, members of Trump's cabinet, and Trump himself. These articles highlighted the use of the wall as political assets used to influence legislation, policymaking, and other political agendas. When reference was made to the border within these articles, it was framed as an American national zone that was under federal jurisdiction, not state or local, thus emphasizing the hierarchies reinforced by a border wall.

Four themes were more closely related to a standard of decent life approach. In regard to protest and dissention and environmental impact U.S. and Mexico newspapers highlighted local issues that directly affected their respective cities. Because the Mexican papers utilized more agency stories and the U.S. newspapers utilized more local reporters, the stories in The El Paso Times and The San Diego Union Tribune included more local government sources and first-hand accounts from citizens living in the border region. It is also important to note that The San Diego Union Tribune had more direct access to local authorities and activist groups who were working with or around the prototypes, therefore, their coverage was more in-depth, nuanced, and tended to have lengthier articles.

The inclusion of more locally-reported stories also gave the U.S. newspapers an added advantage in their coverage of themes that related to safety and security and economic consequences. Their stories provided personal accounts of people living on the border and how 
concerns over personal safety and property were being negotiated. The El Paso Times, more so than The San Diego Union Tribune, had a more balanced coverage of negative and positive consequences in regard to citizens. Both newspapers provided coverage and quotes from federal lawmakers who visited their respective cities to assess security and meet with border patrol agents. The two Mexican newspapers referenced the issues of safety and security, but from a more macro level and focused on Trump and his administration.

Only the U.S. newspapers provided coverage on economic issues and the direct impact a border wall would have for individuals, businesses, and their respective cities. They highlighted local trade, tourism, and commerce. Although the wall itself was positioned to stop the crossing of undocumented immigrants, the ideology of the wall creates friction between not only the U.S. and Mexico, but more specifically border cities. The U.S. articles focused a great deal on employment. Hundreds of people cross the border daily to work. Any hindrance to that flow would severely disrupt the income of Mexican national workers and directly affect businesses in the U.S. who employ them.

The last theme, that of separation and division, had elements of both national zone and standard of life. All four newspapers highlighted the divisions created by the border wall, specifically along party lines in congress and between the U.S. and Mexico. References to the border painted it as a national zone that rhetorically separated factions of people and reinforced a hierarchy of desired bodies. The newspapers also used the border to highlight the actual, physical separation of families. Pictures and stories from individuals speaking to one another through the existing border fences and sharing meals underneath artwork on the border highlight the local impact a wall would have on inhabitants of the border region.

\section{Discussion and Conclusion}

The future of additional U.S.-Mexico border wall and the many consequences it will bring is still unclear, however, the ethos of the situation is best summed up in a quote from The San Diego Union Tribune writer Rick Van Schoik, 'we share not only a border but a future.' In this study, we examine how online newspaper publications in the border cities of San Diego, California and Tijuana, Mexico, and in El Paso, Texas, and Ciudad Juarez, Mexico framed Trump's border wall using Agnew's (2008) theoretical lens of a standard of a decent life. The comparative framing analysis revealed frames of Mexico will pay for the wall; DACA as leverage; political contention; protest and dissention; environmental impact; immigration package; separation and divisiveness; safety and security; and economic consequences. Newspaper articles from the U.S. and Mexico all emphasized the benefits and harms Trump's wall would have on local citizens, businesses, and wildlife. Although there were two themes that framed the border in terms of a U.S. national zone, most themes directly framed the border as a physical territorial space in the borderlands of dwelling and habitat (Agnew, 2008). They specifically did this by interviewing local sources and sharing personal accounts of citizens living within feet of the existing border fences.

The results of this study echo previous framing research that define and construct political issues and public controversy (Entman, 2004; Fryberg et al., 2012; Gross \& D'Ambrosio, 2004; T. Nelson et al., 1997a). This study also adds to framing research by reinforcing the ways in which issues germane to international news, such as the border, become paragons of the evolving political culture using news frames (Antony \& Thomas, 2017; Fernandes \& Shumow, 2016; Frederking, 2012; Varjú \& Plaut, 2017; Vultee, 2010). Issues related to the border were framed as transnational importance, rather than an issue that solely affects one country. Such findings have broader implications for how media frame borders around the world, particularly in regards to 
neoliberalism, political and economic disciplining, and legitimization of physical barriers (Keck \& Clau-Losada, 2021; Rivers \& Ross, 2020).

Most importantly, this study helps to address framing literature on research that focuses on migrants' countries of origin, rather than on their country of resettlement. Only one other study of the sort examined immigration to the United States from Mexico in Mexican newspapers (Muñiz, 2011). The current study reifies that news is often imported and framed from the United States. Mexican newspapers utilized more agencies, whereas U.S. newspapers utilized local reporters. Therefore, U.S. news articles included more localized frames that highlighted standards of a decent life in regard to employment, personal property, issues of safety on the actual borderlands, and activist work in the U.S. Although newspapers on both sides of the border highlighted family separation and physical division, Mexican newspapers highlighted DACA recipients more frequently than U.S. newspapers. On the contrary, U.S. newspapers highlighted economic impact and concerns on safety, whereas the Mexican newspapers did not.

A major strength of this study stems from its focus on a particular event, which contributes empirically to the existing literature on journalistic representations of borders and transnational mobility. Applying the standard of living lens to framing theory allows for a more nuanced and indepth examination on how individuals and spaces of dwelling are framed within transnational news stories. The articles are affective and may potentially elicit more empathetic responses from readers, something that future research should examine. The results from the study's comparative analysis highlight how a transnational issue, such as the border wall, can introduce multiple and diverse assessments in global journalism, while creating an awareness of interconnected global audiences (Reese, 2008). Comparing newspaper coverage of the same issue from both the U.S. and the Mexico provides us with a better understanding of the lived experiences of individuals in relation to both local and global culture (Berglez, 2008). Finally, it makes more apparent the similarities and linkages across cultures (Cottle, 2009). The U.S and Mexico have a symbiotic economic relationship that becomes more significant in the light of a divisive structure, both in terms of physicality and ideology.

This study adds to Agnew's (2008) theoretical concept by helping to define what compromises 'decency' in a transnational border setting. This study's emphasis on Trump's border wall highlights how one particular case can have broader considerations in border studies by contextualizing borders through space and sociopolitical events. This study argues, however, that living a decent life simply is not enough. Individuals in the border regions should be able to thrive in, as well as through, their mestiza identity - an identity that is neither Mexican or American, and forge new forms of knowledge, politics, and epistemologies (Anzaldúa, 2012). This study demonstrates the role of journalism and media in not only that of contextualizing, but also in shaping public opinion through news frames. Journalists, not limited to border cities, should not only have a normative responsibility to represent a standard of decency by weighing both benefits and harms in relation to space and time, but also empower though personal narratives and lived experiences of border dwellers.

This study is not without limitations. Only four international newspapers were analyzed on a six-week timeframe. This choice, however, provided a workable qualitative sample and allowed to concentrate efforts around a specific event (the building of the wall prototypes) in the face of a broader and temporally drawn-out topic (the construction of Trump's border wall itself). Future research may consider including more newspapers and more border cities in Arizona and New Mexico. Also, a reverse causal direction of news should be considered, whereby journalists may be responding to public demands for certain kinds of coverage, particularly when the phenomenon under consideration is in their back yard. 


\section{References}

Aalberg, T., Papathanassopoulos, S., Soroka, S., Curran, J., Hayashi, K., Iyengar, S., Jones, P. K., Mazzoleni, G., Rojas, H., Rowe, D., \& Tiffen, R. (2013). International TV news, foreign affairs interest and public knowledge: A comparative study of foreign news coverage and public opinion in 11 countries. Journalism Studies, 14(3), 387-406. https://doi.org/10.1080/1461670X.2013.765636

About Us. (n.d.). El Paso Times. Retrieved July 12, 2021, from https://static.elpasotimes.com/aboutus/

AFP. (2017, September 21). Demanda California a Donald Trump por construcción del muro. El Sol de Tijuana. https://www.elsoldetijuana.com.mx/mundo/demanda-california-a-donaldtrump-por-construccion-del-muro

Agnew, J. (2008). Borders on the mind: Re-framing border thinking. Ethics \& Global Politics, 1(4), 175-191. https://doi.org/10.3402/egp.v1i4.1892

Akhavan-Majid, R., \& Ramaprasad, J. (1998). Framing and ideology: A comparative analysis of U.S. and Chinese newspaper coverage of the Fourth United Nations Conference on Women the NGO Forum. Mass Communication \& Society, 1(3-4), 131-152. https://doi.org/10.1080/15205436.1998.9677853

Andreas, P. (2009). Border games: Policing the U.S. -Mexico divide. Cornell University Press.

Antony, M. G., \& Thomas, R. J. (2017). "Stop sending your kids across our border:” Discursively constructing the unaccompanied youth migrant. Journal of International \& Intercultural Communication, 10(1), 4-24. https://doi.org/10.1080/17513057.2016.1214282

Anzaldúa, G. (2012). Borderlands: The new Mestiza. Aunt Lute Books.

Associated Press. (2017a, September 12). Desliga casa blanca muro y DACA. El Diario de Juarez. http://diario.mx/Estados_Unidos/2017-09-12_1c790f05/desliga-casa-blanca-muro-y-dacaI

Associated Press. (2017b, September 27). Demanda California al gobierno de Trump por muro fronterizo. El Diario de Juárez. http://diario.mx/Estados_Unidos/2017-0920_98d8a775/demanda-california-al-gobierno-de-trump-por-muro-fronterizo/

Associated Press. (2017c, October 8). Chantajea Trump con DACA a senado para aprobar muro. El Diario de Juárez. http://diario.mx/Estados_Unidos/2017-10-08_2972684e/chantajeatrump-con-daca-a-senado-para-aprobar-muro/

Bauder, D. (2017, October 9). U-T print circulation continues downward spiral | San Diego Reader. San Diego Reader. https://www.sandiegoreader.com/news/2017/oct/09/ticker-u-t-printcirculation-downward-spira/

Berglez, P. (2008). What is global journalism? Theoretical and empirical conceptualizations. Journalism Studies, 9(6), 845-858. https://doi.org/10.1080/14616700802337727

Bixby, K. (2017, September 26). Border wall also a threat to wildlife: Readers. El Paso Times. http://www.elpasotimes.com/story/opinion/2017/09/26/border-wall-also-threat-wildlifereaders/702516001/

Borunda, D. (2017a, September 1). 1,000 march in support of young immigrants, against sanctuary cities law. El Paso http://www.elpasotimes.com/story/news/immigration/2017/09/01/1-000-march-supportyoung-immigrants-against-sanctuary-cities-law/626201001/

Borunda, D. (2017b, September 1). Sen. Ted Cruz focusses on NAFTA, border wall, Obamacare in El Paso visit. El Paso Times. http://www.elpasotimes.com/story/ 
news/politics/2017/08/24/sen-ted-cruz-targets-obamacare-during-el-pasovisit/597749001/

Brito, J. (2017, October 9). A wall won't fix this country's real drug issue. El Paso Times. http://www.elpasotimes.com/story/opinion/2017/10/09/wall-wont-fix-countrys-real-drugissue-readers/725305001/

Brown, W. (2010). Walled states, waning sovereignty. Zone Books.

Caballero, J. (2017, September 1). Muro no contendrá el cruce migrante. El Sol de Tijuana. https://www.elsoldetijuana.com.mx/local/muro-no-contendra-el-cruce-migrante

Camaj, L. (2010). Media framing through stages of a political discourse: International news agencies' coverage of Kosovo's status negotiations. International Communication Gazette, 72(7), 635-653. https://doi.org/10.1177/1748048510378147

Cheng, Z., Caverlee, J., \& Lee, K. (2010). You are where you tweet: A content-based approach to geo-locating twitter users. Proceedings of the 19th ACM International Conference on Information and Knowledge Management - CIKM '10, 759. https://doi.org/10.1145/1871437.1871535

Chong, D., \& Druckman, J. N. (2007). Framing theory. Annual Review of Political Science, 10(1), 103-126. https://doi.org/10.1146/annurev.polisci.10.072805.103054

Collins, E. (2017, September 1). Nevada Rep. Mark Amodei tries to be a "pro-immigration republican" in the era of Trump. El Paso Times. https://www.elpasotimes.com/story/news/politics/2017/09/01/nevada-rep-mark-amodeipro-immigration-republican-trump-era/620298001/

Cooper, M., \& Kuhn, P. (2020). Behavioral job search. Handbook of Labor, Human Resources and Population Economics, 83(3), 195-216. https://doi.org/10.1177/1748048520913230

Coronado, I., \& Mumme, S. (2020). Environmental governance at the US-Mexico Border. In T. Payan \& P. L. Cruz (Eds.), Binational commons: Institutional development and governance on the US-Mexico Border (pp. 159-190). University of Arizona Press.

Cottle, S. (2009). Global crisis reporting. McGraw-Hill Companies, Incorporated.

Curran, J., Esser, F., Hallin, D. C., Hayashi, K., \& Lee, C.-C. (2017). International news and global integration: A five-nation reappraisal. Journalism Studies, 18(2), 118-134. https://doi.org/10.1080/1461670X.2015.1050056

Demirjian, K. (2017, September 3). Trump surrogates say ending DACA could be good for U.S. workers. The San Diego Union Tribune. https://www.sandiegouniontribune.com/news/uspolitics/ct-trump-ending-daca-20170903-story.html

Di Renzo, F. (2017). Exploring online news: What elpais.com 's and eldiario.es 's narratives tell about the migrant crossings of the Morocco-Spain border. Journalism, 21(7), 974-989. https://doi.org/10.1177/1464884917708866

Duan, R., \& Takahashi, B. (2017). The two-way flow of news: A comparative study of American and Chinese newspaper coverage of Beijing's air pollution. International Communication Gazette, 79(1), 83-107. https://doi.org/10.1177/1748048516656303

Elcioglu, E. F. (2017). The state effect: Theorizing immigration politics in Arizona. Social Problems, 64(2), 239-255. https://doi.org/10.1093/socpro/spw060

Elena, M. (2016). Framing international media in the face of social movements: CNN and AlJazeera English in the fall of Morsi. Communication \& Society, 29(3), 119-130. https://doi.org/10.15581/003.29.3.119-130

Entman, R. (1993). Framing: Toward clarification of a fractured paradigm. Journal of Communication, 43(4), 51-58. https://doi.org/10.1111/j.1460-2466.1993.tb01304.x 
Entman, R. (2004). Projections of power: Framing news, public opinion, and U.S. foreign policy. University of Chicago Press.

Entman, R. (2007). Framing bias: Media in the distribution of power. Journal of Communication, 57(1), 163-173. https://doi.org/10.1111/j.1460-2466.2006.00336.x

Entman, R., Matthes, J., \& Pellicano, L. (2009). Nature, sources, and effects of news framing. In K. Wahl-Jorgensen \& T. Hanitzsch (Eds.), The handbook of journalism studies. (pp 195210) Routledge.

Febriyanti, I. (2017). Trump's border wall: The flurry loss of immigrants' rights and reshaping immigration law. Jurnal Komunikasi Hukum (JKH), 3(1), 96-104. https://doi.org/10.23887/jkh.v3i1.9245

Fernandes, J., \& Shumow, M. (2016). Framing politics in transnational communities: Spanishlanguage immigrant media and election coverage in South Florida. Journalism, 17(8), 961978. https://doi.org/10.1177/1464884914542743

Finnegan, M. (2016, June 2). “It's going to be a big, fat, beautiful wall!": Trump's words make his California climb an even steeper trek. Los Angeles Times. https://www.latimes.com/politics/la-na-pol-trump-california-campaign-20160602-snapstory.html

Flores, R. (2017, September 4). Opinion: Better ways to spend money than a border wall. The San Diego Union Tribune. https://www.sandiegouniontribune.com/opinion/letters-to-theeditor/sd-broder-wall-hurricane-houston-utak-letters-20170901-story.html

Frederking, L. (2012). A comparative study of framing immigration policy after 11 September 2001. Policy Studies, 33(4), 283-296. https://doi.org/10.1080/01442872.2012.694184

Fryberg, S. A., Stephens, N. M., Covarrubias, R., Markus, H. R., Carter, E. D., Laiduc, G. A., \& Salido, A. J. (2012). How the media frames the immigration debate: The critical role of location and politics: Immigration debate (SB 1070). Analyses of Social Issues \& Public Policy, 12(1), 96-112. https://doi.org/10.1111/j.1530-2415.2011.01259.x

Gobierno de México. (2021). Padrón nacional de medios impresos-Consulta de medios. Gobierno de México. https://pnmi.segob.gob.mx/reporte

Goffman, E. (1974). Frame analysis: An essay on the organization of experience. Harper \& Row.

Gómez, G. (2017, September 28). Why Trump's wall is a bad deal for San Diego. The San Diego Union Tribune. http://www.sandiegouniontribune.com/opinion/ commentary/sd-utbgtrump-wall-border-economy-20170928-story.html

Gravelle, T. B. (2018). Politics, time, space, and attitudes toward US-Mexico border security. Political Geography, 65, 107-116. https://doi.org/10.1016/j.polgeo.2018.05.012

Gross, K., \& D’Ambrosio, L. (2004). Framing emotional response. Political Psychology, 25(1), 129. JSTOR.

Harlow, S., \& Johnson, T. J. (2011). Overthrowing the protest paradigm? How the New York Times, Global Voices and Twitter covered the Egyptian revolution. International Journal of Communication, 5, 1359-1374.

Hastings, M. (2017, October 12). Demanda casa blanca precio muy alto por amparo a dreamers. El Diario de Juárez. http://diario.mx/Opinion_El_Paso/2017-10-11_eee3c532/demandacasa-blanca-precio-muy-alto-por-amparo-a-dreamers/

Hernández, J. (2017, September 30). Autoridades en Tijuana blindan zonas cercanas a construcción del muro. El Sol de Tijuana. https://www.elsoldetijuana.com.mx/sociedad/autoridades-en-tijuana-blindan-zonascercanas-a-construccion-del-muro 
Heyman, J., \& Ackleson, J. (2010). United States border security after 9/11. In J. A. Winterdyk \& K. W. Sundberg (Eds.), Border security in the Al-Qaeda era (pp. 37-76). CRC Press.

Hinton, K. A. (2017). Beginning from the border. Educational Borderlands: A Bilingual Journal, $1,3-14$.

Hove, T., Paek, H.-J., Isaacson, T., \& Cole, R. T. (2013). Newspaper portrayals of child abuse: frequency of coverage and frames of the issue. Mass Communication \& Society, 16(1), 89108. https://doi.org/10.1080/15205436.2011.632105

Iyengar, S. (1991). Is anyone responsible? How television frames political issues. The University of Chicago Press. https://press.uchicago.edu/ucp/books/book/chicago///bo3684515.html

Jang, W. Y. (2013). News as propaganda: A comparative analysis of US and Korean press coverage of the Six-Party Talks, 2003-2007. International Communication Gazette, 75(2), 188-204. https://doi.org/10.1177/1748048512465555

Jenkins, R. (2014). Social identity. Routledge.

Kaiser, J., \& Kleinen-von Königslöw, K. (2017). The framing of the Euro crisis in German and Spanish online news media between 2010 and 2014: Does a common European public discourse emerge?: The framing of the Euro crisis. JCMS: Journal of Common Market Studies, 55(4), 798-814. https://doi.org/10.1111/jcms.12515

Keck, M., \& Clua-Losada, M. (2021). Trump's authoritarian neoliberal governance and the USMexican border. Policy Studies, 1-17. https://doi.org/10.1080/01442872.2021.1959541

Konieczna, M., Mattis, K., Tsai, J.-Y., Liang, X., \& Dunwoody, S. (2014). Global journalism in decision-making moments: A case study of Canadian and American television coverage of the 2009 United Nations Framework Convention on climate change in Copenhagen. Environmental Communication, 8(4), 489-507. https://doi.org/10.1080/17524032.2014.909509

Lawlor, A. (2015). Local and national accounts of immigration framing in a cross-national perspective. Journal of Ethnic \& Migration Studies, 41(6), 918-941. https://doi.org/10.1080/1369183X.2014.1001625

Lindlof, T. R., \& Taylor, B. C. (2002). Qualitative communication research methods. SAGE.

Liobikienè, G., Grincevičienè, Š., \& Bernatonienè, J. (2017). Environmentally friendly behaviour and green purchase in Austria and Lithuania. Journal of Cleaner Production, 142, 37893797. https://doi.org/10.1016/j.jclepro.2016.10.084

Löffelholz, M., \& Weaver, D. (2008). Global journalism research. Summing up and looking ahead. In M. Löffelholz, D. Weaver, \& A. Schwarz (Eds.), Global journalism research: Theories, methods, findings, future. (pp 285-294). Wiley.

López, E. (2017, Ocober). México alista debate para frenar el muro. El Sol de Tijuana. https://www.elsoldetijuana.com.mx/local/mexico-alista-debate-para-frenar-el-muro

Lück, J., Wessler, H., Wozniak, A., \& Lycarião, D. (2018). Counterbalancing global media frames with nationally colored narratives: A comparative study of news narratives and news framing in the climate change coverage of five countries. Journalism, 19(12), 1635-1656. https://doi.org/10.1177/1464884916680372

Marchionni, D. M. (2012). International human trafficking: An agenda-building analysis of the US and British press. International Communication Gazette, 74(2), 145-158. https://doi.org/10.1177/1748048511432600

Mascaro, L. (2017, September 5). Speaker Ryan has 'hope' Congress can protect 'Dreamers,' but few other Republicans join Democratic pledge to fix DACA. The San Diego Union Tribune. http://www.sandiegouniontribune.com/news/us-politics/la-dreamers-decision-liveupdates-speaker-ryan-has-hope-congress-can-1504629054-htmlstory.html 
McDonnell, P. (2017a, August 31). Mexico signals tougher stance on NAFTA, may pull out of talks if Trump moves to scrap deal. The San Diego Union Tribune. http://www.sandiegouniontribune.com/news/nation-world/la-fg-mexico-nafta-20170831story.html

McDonnell, P. (2017b, September 2). Mexican president says country will not compromise its "dignity" when dealing with the U.S. The San Diego Union Tribune. https://www.sandiegouniontribune.com/news/nation-world/la-fg-mexico-pena-nieto20170902-story.html

McDonnell, P. (2017c, September 4). Where the border fence meets the sea, a strange beach scene contrasting the U.S. and Mexico. The San Diego Union Tribune. http://www.sandiegouniontribune.com/news/nation-world/ct-mexico-tijuana-beach-20170904-story.html

McDonnell, P. (2017d, September 5). Mexico greets Trump's DACA decision with 'profound regret.' The San Diego Union Tribune. http://www.sandiegouniontribune.com/news/uspolitics/la-dreamers-decision-live-updates-mexico-greets-trump-s-daca-decision1504635249-htmlstory.html

McGahern, U. (2017). Protesting at the crossroads: Framing 'in-between places' in spatial analyses of contention. Political Geography, 59, 92-102. https://doi.org/10.1016/j.polgeo.2017.04.006

Media Bias / Fact Check. (2020a, August 8). San Diego Union Tribune. https://mediabiasfactcheck.com/san-diego-union-tribune/

Media Bias / Fact Check. (2020b, September 23). El Paso Times. https://mediabiasfactcheck.com/el-paso-times/

Mientras Pence elogia a hispanos, Trump condiciona su muro por solución al DACA. (2017, October 11). El Sol de Tijuana. https://www.elsoldetijuana.com.mx/mundo/mientraspence-elogia-a-hispanos-trump-condiciona-su-muro-por-solucion-al-daca

Mekelburg, M. (2017a, October 4). Bill would ban eminent domain for border wall. El Paso Times. http://www.elpasotimes.com/story/news/immigration/2017/10/04/bill-would-baneminent-domain-border-wall/731314001/

Mekelburg, M. (2017b, October 10). Texas democrats in Congress balk at Trump's immigration plan. El Paso Times. http://www.elpasotimes.com/story/news/immigration/2017/10/10/texas-democratscongress-balk-trumps-immigration-plan/750864001/

Mogos, A., Vincze, H. O., \& Meza, R. M. (2021). Domesticating foreign news in Romanian news outlets: Global issues in local frames. Romanian Journal of Sociological Studies, 1(1), 517. https://journalofsociology.ro/

Moran, G. (2017, October 3). As wall prototypes go up, DHS report says sneaking across southwest border now harder than ever before. The San Diego Union Tribune. http://www.sandiegouniontribune.com/news/border-baja-california/sd-me-border-report20171002-story.html

Moran, G., \& Davis, K. (2017, September 26). Construction begins on Trump's border wall prototypes in Otay Mesa. The San Diego Union Tribune. http://www.sandiegouniontribune.com/news/border-baja-california/sd-me-border-begins20170926-story.html

Morrissey, K. (2017, September 1). Construction set to begin on prototypes for Trump's U.S.Mexico border wall. The San Diego Union Tribune. 
http://www.sandiegouniontribune.com/news/california/la-me-border-wall-20170901story.html

Muñiz, C. (2011). Encuadres noticiosos sobre migración en la prensa digital mexicana. Un análisis de contenido exploratorio desde la teoría del framing. Revista de Ciencias Sociales, 55, 213-239.

Nelson, S. (2011). The immigrant experience: Mexico and Central America to the United States. California Polytechnic State University.

Nelson, T., \& Kinder, D. (1996). Issue frames and group-centrism in American public opinion. The Journal of Politics, 58(4), 1055-1078. JSTOR. https://doi.org/10.2307/2960149

Nelson, T., Clawson, R., \& Oxley, Z. (1997a). Media framing of a civil liberties conflict and its effect on tolerance. American Political Science Review, 91(3), 567-583. https://doi.org/10.2307/2952075

Nelson, T., Oxley, Z., \& Clawson, R. (1997b). Toward a psychology of framing effects. Political Behavior, 19(3), 221-246.

Nevins, J. (2001). Operation Gatekeeper: The rise of the "illegal alien" and the making of the U.S.-Mexico boundary. Routledge.

Notimex. (2017, September 1). Beso del meñique, símbolo de reencuentro. El Sol de Tijuana. https://www.elsoldetijuana.com.mx/dos-mil-millas/beso-del-menique-simbolo-dereencuentro

Olive, A., \& Delshad, A. B. (2017). Fracking and framing: A comparative analysis of media coverage of hydraulic fracturing in Canadian and US newspapers. Environmental Communication, 11(6), 784-799. https://doi.org/10.1080/17524032.2016.1275734

Paletta, D., Debonis, M., \& O'Keefe, E. (2017, September 3). With brutal Sept. To-do list, GOP already clashing over Harvey relief, debt limit. The San Diego Union Tribune. https://www.sandiegouniontribune.com/news/us-politics/ct-republicans-harvey-debtlimit-20170903-story.html

Pantti, M. (2013). Seeing and not seeing the Syrian crisis: New visibility and the visual framing of the Syrian conflict in seven newspapers and their online editions. JOMEC Journal, O(4). https://doi.org/10.18573/j.2013.10259

Reese, S. D. (2008). Theorizing a globalized journalism. In M. Löffelholz, D. Weaver, \& A. Schwarz (Eds.), Global journalism research: Theories, methods, findings, future (pp. 240251). Wiley.

Reforma. (2017a, September 26). Alista EU colocación de prototipos de muro. El Diario de Juárez. http://diario.mx/Estados_Unidos/2017-09-26_f9fa7b04/alista-eu-colocacion-deprototipos-de-muro-\&ref=1/

Reforma. (2017b, September 26). Inicia construcción de prototipos de muro. El Diario de Juárez. http://diario.mx/Nacional/2017-09-26_01cf36ed/inicia-construccion-de-prototipos-demuro-l

Reuters. (2017, October 8). Trump envía futura reforma migratoria: Pide más fondos para muro y prohíbe dreamers. El Sol de Tijuana. https://www.elsoldetijuana.com.mx/mundo/trumppresenta-decalogo-migratorio-pide-mas-fondos-para-muro-y-prohibe-ingreso-de-dreamers

Rivers, D. J., \& Ross, A. S. (2020). Authority (de) legitimation in the border wall Twitter discourse of President Trump. Journal of Language \& Politics, 19(5), 831-856. https://doi.org/10.1075/jlp.19105.riv

Romero, L. A., \& Zarrugh, A. (2017). Islamophobia and the making of Latinos/as into terrorist threats. Ethnic \& Racial Studies, 41(12), 2235-2254. https://doi.org/10.1080/01419870.2017.1349919 
Rosas-Moreno, T. C., \& Bachmann, I. (2012). Pakistani and U.S. press content on Benazir Bhutto's assassination frame her dynasty, destiny, death and their secrets. 30.

Sarabia, H. (2020) Migrants, activists, and the Mexican State: Framing violence, rights, and solidarity along the U.S.-Mexico border. Citizenship Studies, 2(4), 512-529. https://doi.org/10.1080/13621025.2020.1755175

SBCC, S. B. C. C. (2021, July 11). Fatal encounters with CBP. Southern Border Communities Coalition. https://www.southernborder.org/deaths_by_border_patrol

Shehata, A., \& Hopmann, D. N. (2012). Framing climate change: A study of US and Swedish press coverage of global warming. Journalism Studies, 13(2), 175-192. https://doi.org/10.1080/1461670X.2011.646396

Showley, R. (2017, August 31). Shut down the government if a border wall isn't funded? EconoMeter panelists weigh in on Trump's threat. - The San Diego Union-Tribune. The San Diego Union Tribune. https://www.sandiegouniontribune.com/business/economy/sdfi-econometer3sept-20170831-htmlstory.html

Stone, K. (2020, October 22). Daily U-T circulation drops to 88,000: Publisher calls outlet "healthy, profitable." Times of San Diego. https://timesofsandiego.com/business/2020/10/21/daily-u-t-circulation-drops-to-88000publisher-calls-outlet-healthy-profitable/

Trump da marcha atrás con paralizar gobierno si no financian muro. (2017, September 1). El Sol de Tijuana. https://www.elsoldetijuana.com.mx/mundo/trump-da-marcha-atras-conparalizar-gobierno-si-no-financian-muro-2

Ulloa, J. (2017, October 5). California becomes 'sanctuary state' in rebuke of Trump immigration policy. The San Diego Union Tribune. http://www.sandiegouniontribune.com/news/uspolitics/la-pol-ca-brown-california-sanctuary-state-bill-20171005-story.html

Varjú, V., \& Plaut, S. (2017). Media mirrors? Framing Hungarian Romani migration to Canada in Hungarian and Canadian press. Ethnic and Racial Studies, 40(7), 1096-1113. https://doi.org/10.1080/01419870.2017.1266007

Vaughan-Williams, N. (2009). Front Matter. In Borderpolitics: The limits of sovereign power. Edinburgh University Press. http://www.jstor.org/stable/10.3366/j.ctt1r29sk.1

Vines, R. (2017, September 1). Send a loud message against Trump's border wall. El Paso Times. https://www.elpasotimes.com/story/opinion/2017/09/01/fee-increases-city-pools-toohigh/617682001/

Vultee, F. (2010). Securitization as a media frame: What happens when the media 'speak security. In M. J. Trombetta \& T. Balzacq (Eds.), Securitization theory: How security problems emerge and dissolve (pp. 77-93). Routledge.

Winkley, L., \& Repard, P. (2017, September 5). Jury in Banda case deadlocks on hit and run, convicts on misdemeanors. The San Diego Union Tribune. http://www.sandiegouniontribune.com/news/courts/sd-me-banda-verdict-20170905story.html

Zaharopoulos, T. (2007). The news framing of the 2004 olympic games. Mass Communication \& Society, 10(2), 235-249. https://doi.org/10.1080/15205430701265752

Zhang, X., \& Hellmueller, L. (2017). Visual framing of the European refugee crisis in Der Spiegel and CNN International: Global journalism in news photographs. International Communication Gazette, 79(5), 483-510. https://doi.org/10.1177/1748048516688134 


\section{Notes on Contributors}

Nathian Shae Rodriguez, Ph.D. is an Associate Professor of Digital Media in the School of Journalism \& Media Studies at San Diego State University. He specializes in critical-cultural and digital media studies, critical communication pedagogy, and pop culture pedagogy. His research focuses on minority representation in media, specifically LGBTQ and Latinx portrayals and intersectional identity negotiation, as well as pop culture, identity, radio broadcasting, and issues of masculinity/mascing. https://orcid.org/0000-0001-7605-3262

Mariana De Maio, Ph. D. is an Assistant Professor in the Department of Journalism and Communication at Lehigh University. She is a political communication and journalism studies scholar. Her teaching and research interests lie in media influence on political attitudes and behavior, digital media activism, influences in journalistic practices, and portrayals of women and other underrepresented/misrepresented groups in media. https://orcid.org/0000-0002-5033-8574 